\title{
Mirabad-e Emam Qoli: a newly discovered Sassanid-era fire temple in south-eastern Iran
}

Leyla Fazel $^{1,{ }^{*}} \&$ Yaghoub Mohammadifar ${ }^{1}$

In 2013, archaeological survey at the Bam World Heritage site of the eastern part of Kerman Province in Iran discovered the remains of a previously undocumented Sassanid fire temple.

Keywords: Iran, Kerman province, Sassanid, fire temple

\section{Geographic location}

What remains of the Mirabad-e Emam Qoli fire temple is located in the eastern part of Kerman Province in south-eastern Iran. This area represents the southern margin of the Kavir-e Lut (Lut Desert), and thus experiences an arid desert climate, windstorms and sandstorms. The fire temple is located $12 \mathrm{~km}$ to the north of Mohammadabad (the capital of Rigan County) in Mirabad-e Emam Qoli Village, at 28 $45^{\prime} 2^{\prime \prime}$ north and 58 $59^{\prime} 25^{\prime \prime}$ east, and at an elevation of $600 \mathrm{~m}$ asl (Figures 1-2). It was discovered in 2013 during archaeological survey undertaken in order to understand the cultural landscape of Bam (Fazel 2012-2015: 1320).

\section{Description of the Mirabad-e Emam Qoli fire temple}

The structure consists of a single building featuring the typical characteristics of Sassanid religious architecture. The main building is a rectangular structure measuring $13 \times 17.4 \mathrm{~m}$. The ground plan of this area includes a cruciform central chamber, four doorways on the four sides and a vestibule around the central space. The chamber in the centre measures $4 \times 4 \mathrm{~m}$. The depth of the doorways is $3.3 \mathrm{~m}$ on the north side, and $2.1 \mathrm{~m}$ on the other three sides. The vestibules are $3.25 \mathrm{~m}$ wide along the north side, and nearly $1.3 \mathrm{~m}$ wide on the other sides. The vestibules lead to the area surrounding the fire temple through doorways in each of the four sides. Remnants of a chamber measuring $3.1 \times 5.4 \mathrm{~m}$ along the west side and another one measuring $3.3 \times 3 \mathrm{~m}$ on the south side are still standing (Figures $3-4$ ). The tallest part of the structure, along the eastern side, is $1.6 \mathrm{~m}$ high. The structure is mostly covered with debris and sand up to the rise of the arches of the doorways (Figure 5). The walls are covered with clay and straw. The main part of the structure is currently situated below ground level and cannot be seen from a distance. The roofing has not survived in most parts of the 


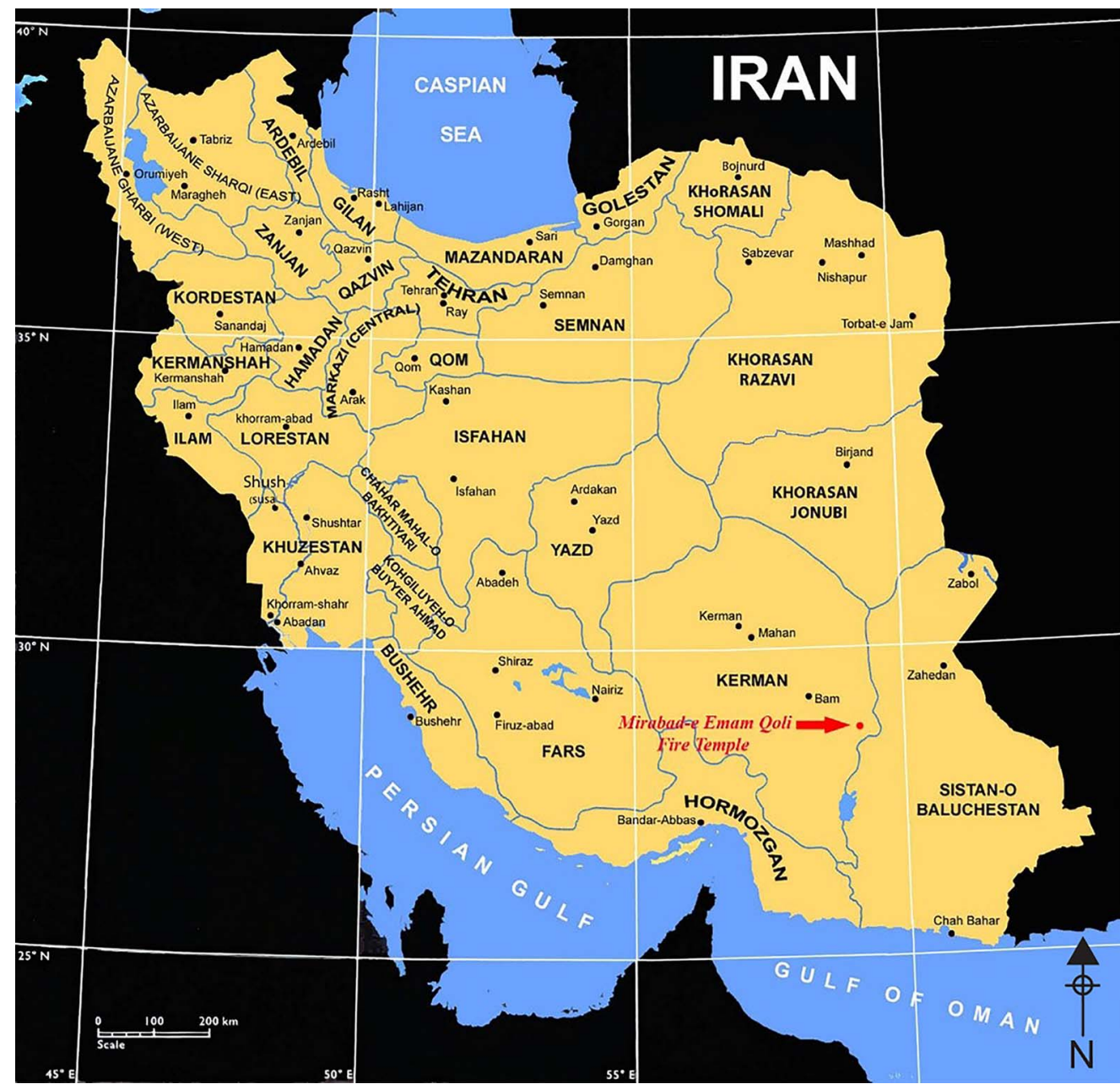

Figure 1. Map of Iran, with location of the Mirabad-e Emam Qoli fire temple (map by the authors).

building. There are extensions and additions to the building on all sides, the remnants of which have formed mounds around the main structure.

The most significant feature of this structure is the fire altar at the centre. The upper compartment of the altar is a cube measuring $1.6 \mathrm{~m}$ on each side, and has at least four stepped layers. The fire altar confirms the function of the structure as a fire temple (Figure 5). The visible part of the fire altar is made of large baked bricks covered with a gypsum plaster. The censer is covered with debris. There is a hole in one of the corners of the fire altar, which was presumably used to feed the flames with oils or other aromatic substances. In a nask (chapter) of the Sassanid Avesta (the holy book of Zoroastrian), an account of the worshipping ritual says that the fragrance of frankincense and other incenses lingered in the fire temple (Christensen 1999: 237). The visible parts of the fire altar are similar to those depicted on Sassanid coins, and to the stone fire altar of Qanat Baq. The fire altar is situated slightly (C) Antiquity Publications Ltd, 2019 


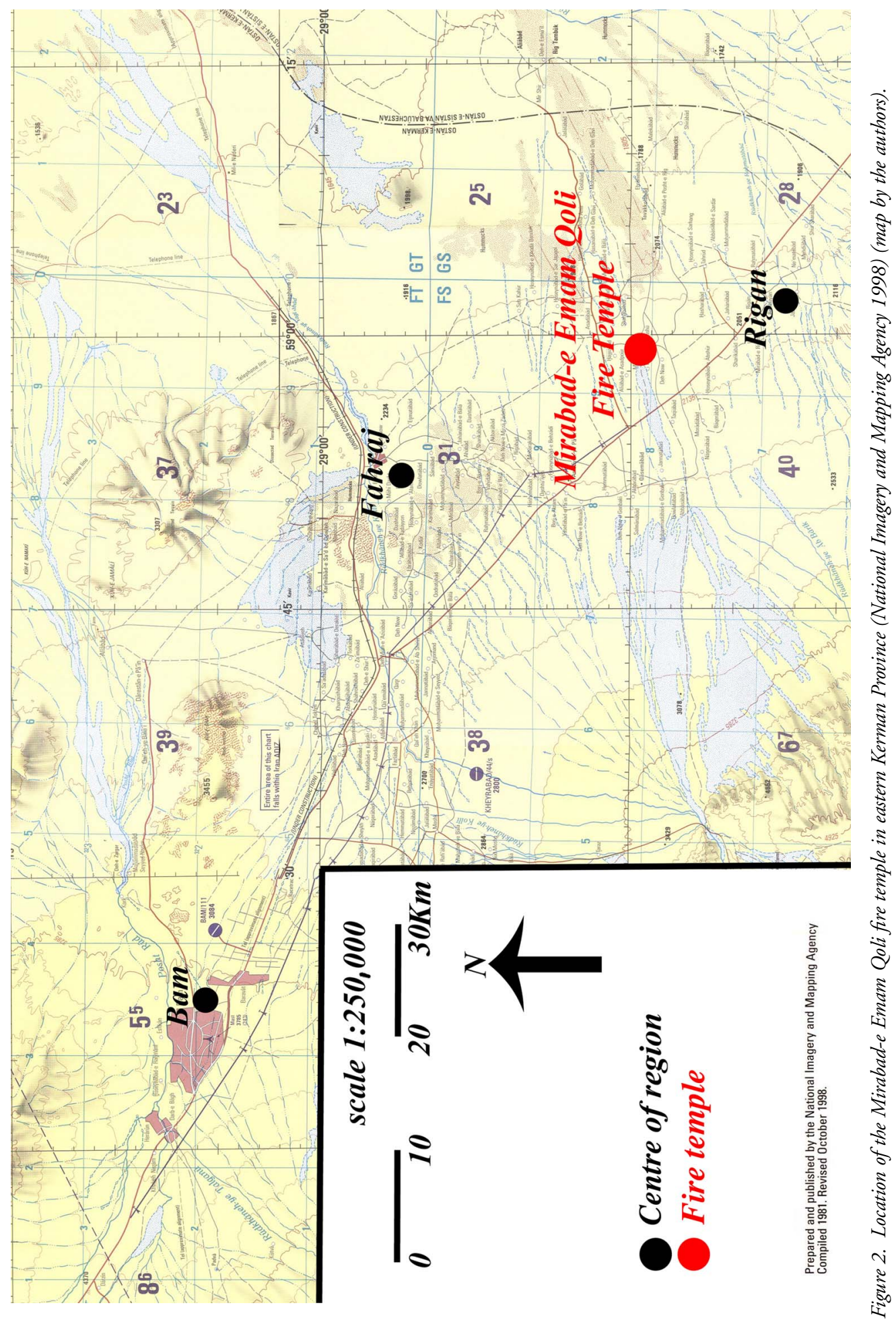

(C) Antiquity Publications Ltd, 2019 


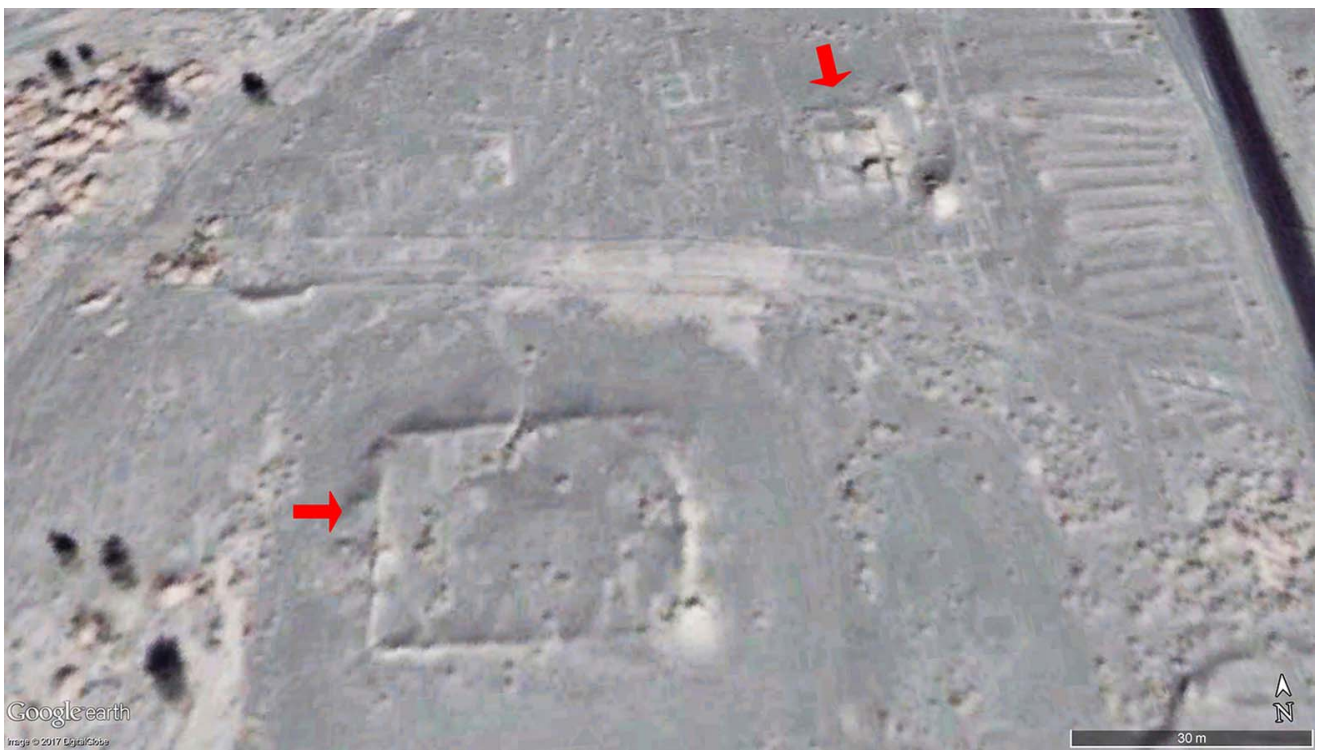

Figure 3. Aerial image of the fire temple (top-right arrow) and the possible castle/caravansary/accommodation block (bottom-left arrow) (Google Earth 2017) (image by the authors).

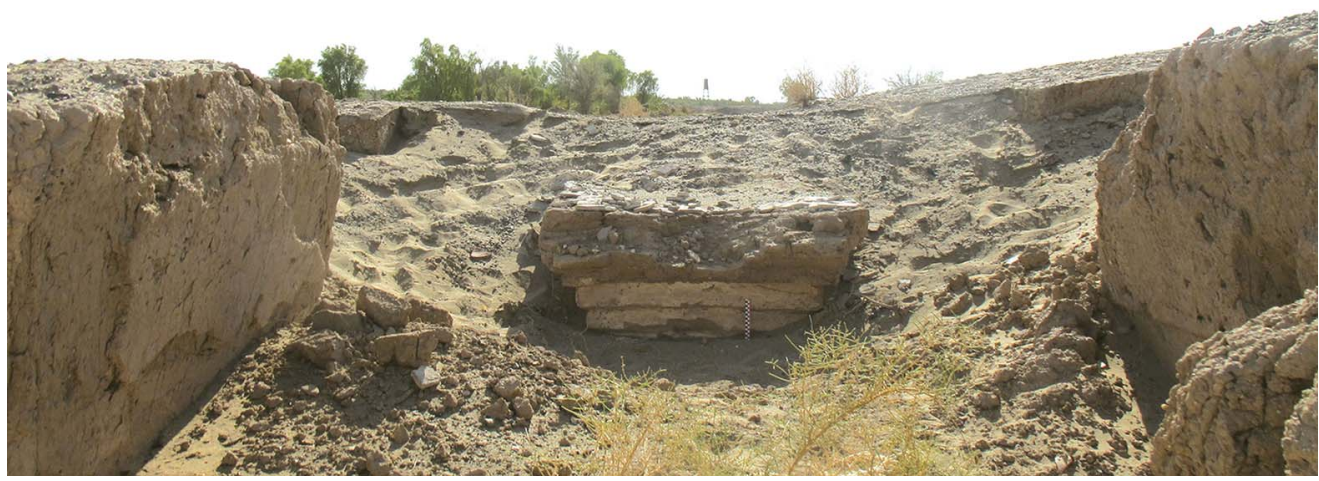

Figure 4. The east side of the fire temple (Fazel 2012-2015: figs 200-202) (photograph by Leyla Fazel).

below the rise of the eastern arch, which suggests that the fire altar pedestal originally featured a rather tall, column-like structure. The exact form of the main altar slab and its supports is, however, unknown due to the debris that covers them.

The building is mainly made of bricks measuring $0.4 \times 0.4 \times 0.1 \mathrm{~m}$. The plan of this fire temple is similar to that of the Konar Siyah, Tol Jangi and Khormayak fire temples in Fars, the Negar fire temple in Kerman, the Juliyan fire temple in Abdanan and the Mil-e Milgah fire temple in Kermanshah (Vanden Berghe 1961: plans II, III \& IV; Azad 2005: 282; Moradi 2009: (C) Antiquity Publications Ltd, 2019 


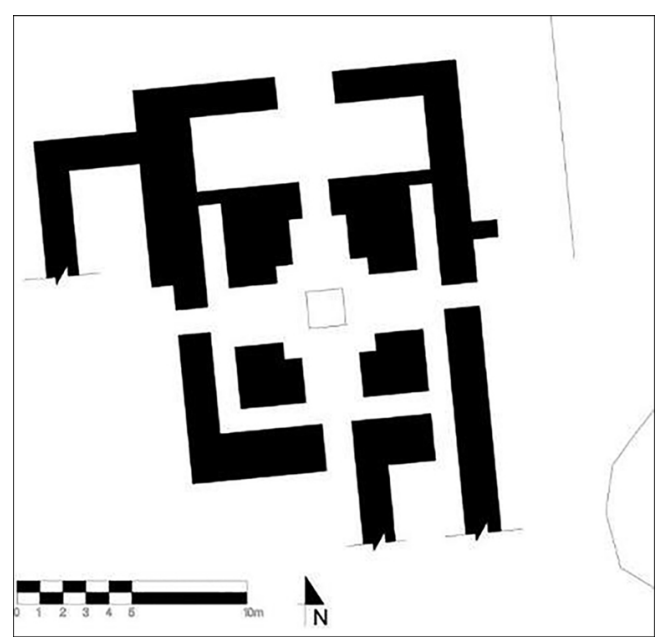

Figure 5. Map of the Mirabad-e Emam Qoli fire temple (Fazel 2012-2015: plan 200-1).

\section{References}

AzAD, M. 2005. Transformation of the Sassanid religious buildings to Islamic religious buildings: a study. Unpublished PhD dissertation, Tarbiyat Modarres University.

Christensen, A.E. 1999. Sassanid Persia. Tehran: Seda-ye Mo'aser.

FAZEL, L. 2012-2015. Unpublished report of archaeological studies of the cultural landscape of Bam. Preliminary study of the castles in the cultural landscape and on the cultural trail of Bam-Bam, Narmashir, Fahraj, Rigan. Supervised by Shahriar
179, plan 6; Mohammadifar \& Motarjem 2011: 79, plan 1). While these all date back to the Sassanid reign, finer chronological precision is not currently possible.

Evidence from aerial images suggests that the fire temple was surrounded by several other buildings (Figure 3). The structures that can still be distinguished are located to the south-west of the temple, and stand on a mound approximately $5 \mathrm{~m}$ in height. The ground plan is rectangular, measuring $31 \times 41 \mathrm{~m}$. This was probably a castle, caravansary or a similar type of accommodation block. Such complexes are often associated with Sassanid fire temples and would have provided pilgrims and site attendants with accommodation.

Adl, Document Centre of the World Heritage Site of Bam and its Cultural Landscape, Document Center of ICHTO Centre for Archaeological Research.

Mohammadifar, Y. \& A. Motarjem. 2011. Juliyan: a newly discovered Sassanid fire temple in Abdanan. Baq-e Nazar 19: 77-88.

Moradi, Y. 2009. Mil-e Milgah Chahartaq: a Sassanid fire temple. Archeological Studie (Faculty of Literature and Humanities University of Tehran) 1: 155-83.

VANDEN Berghe, L. 1961. Récentes découvertes de monuments sassanides dans le Fars. Iranica Antiqua I: 163-200. 